\title{
CSR commitments, perceptions of hypocrisy, and recovery
}

\author{
Dustin Smith ${ }^{*}$ iD and Eric Rhiney
}

\begin{abstract}
This paper examines perceived hypocrisy when a failure is aligned with prior social performance. It is hypothesized that commitment to a CSR domain creates greater performance expectations thus exacerbating the effects when an aligned failure occurs. Study 1 demonstrates that failure alignment and severity increase perceived hypocrisy which negatively impacts customer evaluations of trust, repurchase intent, and brand attitude. Study 2 evaluates two response strategies of apology and compensation vs. no response. An apology significantly reduced perceptions of hypocrisy only when the failure was unaligned with prior CSR. Compensation significantly reduced hypocrisy in both the unaligned and aligned conditions.
\end{abstract}

Keywords: Corporate social responsibility, Corporate hypocrisy, Reputation recovery

\section{Maintext}

Shifting perceptions regarding the role of business in society has lead firms to consider the broader outcomes of activities beyond simple profit maximization. Pressure from stakeholder groups has translated into firms adopting policies aimed at generating favorable perceptions of corporate citizenship, corporate social responsibility (CSR) and business ethics. Take, for example, a survey by Cone Communications in which $94 \%$ of respondents said businesses have at least some higher-order obligations beyond the shareholder wealth maximization (Cone Communications., 2017). These findings support the assertion that social outcomes should be considered alongside traditional strategic goals.

However, while the link between CSR and measurable business outcomes is often unclear (McWilliams \& Siegel, 2000), several studies have shown that corporate citizenship may contribute to a positive firm reputation (Lai, Chiu, Yang, \& Pai, 2010; Tetrault Sirsly \& Lvina, 2019). In other cases, research has shown that CSR adds robustness to a firm's reputation, a "buffering effect" (Godfrey, 2005; Kim, 2014; Peloza, 2006) or the ability to protect firms against the negative outcomes of an adverse event such as a product recall or environmental misstep. For example, CSR lead to more favorable attributions by consumers

\footnotetext{
* Correspondence: dustinsmith64@webster.edu
}

Management, Webster University, St. Louis, USA following a product crisis (Klein \& Dawar, 2004), protected firm value following regulatory action (Godfrey, Merrill, \& Hansen, 2009), or positively influenced consumer actions following a negative event (Kim \& Woo, 2019).

In contrast to a buffering effect, other studies have noted how a reputation for CSR in the presence of social irresponsibility can lead to perceptions of hypocrisy (Janney \& Gove, 2011; Lenz, Wetzel, \& Hammerschmidt, 2017; Wagner, Lutz, \& Weitz, 2009).

Hypocrisy is a state in which CSR claims are inconsistent with a firm's internal processes or a discrete external event (Ioannou, Kassinis, \& Papagiannakis, 2018). Paradoxically, a consumer's negative view of the event may actually be amplified. As firms engage in CSR they shape stakeholders' perceptions by creating signals of underlying values which may positively impact a firm's reputation (Tetrault Sirsly \& Lvina, 2019). However, in the case of wrong-doing, the event may contradict these signals and engender feelings which call into question a firm's claims. For example, Janney and Gove (2011) found that negative effects were exacerbated when a firm with a positive reputation for good governance was found to be involved in a governance-related scandal.

While studies into the shielding characteristics of a CSR reputation are promising, few consider the multidimensional nature of CSR when ascertaining 
hypocrisy. A firm can target its social efforts at a variety of CSR subdomains such as its employees, the local community, or environmental sustainability (Öberseder, Schlegelmilch, \& Murphy, 2013). Few studies consider how the domain of the crisis situation and the domain of prior CSR actions may interact to alter consumer perception of the event. For instance, would stakeholders perceive a firm as hypocritical if the wrong-doing occurs in an area unrelated to a firm's CSR efforts? In order to fill this gap, this study proposes that when a failure occurs in a domain aligned with the firm's prior focus of citizenship efforts, the resulting effect will be greater feelings of hypocrisy among consumers compared to an unaligned domain.

Secondly, this paper contributes to the reputation and recovery literature by examining domain alignment effects on three generic recovery strategies, In doing so, this paper helps answer the call for further investigation into the process of loss and recovery of a firm's approval (Westphal \& Deephouse, 2011).

\section{Corporate social responsibility}

CSR is the collection of responsibilities that a firm has towards society (Carroll, 1991). It represents the efforts by an organization to improve the lives of various stakeholders or create positive changes in the external environment (Dahlsrud, 2008), or a means by which a firm seeks social legitimacy (Pollach, 2015).

Rather than existing as a single construct, the umbrella term CSR can be conceptualized as a collection of various domains, sub domains, and behaviors which highlight responsibilities aimed at various stakeholder groups. For purposes of sensemaking and analysis, several scholars have adopted differing domain classifications. For example, in his foundational paper, Archie Carroll (1991) described the umbrella of CSR in 4 parts, namely economic, legal, ethical, and philanthropic responsibilities. Matten and Moon (2008) partitioned CSR into "explicit" and "implicit" components. Explicit actions are classified as voluntary philanthropic actions directed towards internal or external stakeholders for the purposes of social or shared value creation. Implicit CSR are actions undertaken seemingly through the normal course of business which creates social value such as high wages and benefits for employees. Further, (Cornelius, Todres, Janjuha-Jivraj, Woods, \& Wallace, 2008) examined CSR in the context of internal vs. external CSR denoting actions targeted towards stakeholders based upon their relationship to the firm. Reporting frameworks such as the Global Reporting Initiative and assess firms across a variety of domains such as performance regarding the natural environment, labor, corporate governance and fiscal responsibility.

Likewise, this paper adopts a multidimensional view of reputation for CSR. Rather than existing as a generalized assessment of a firm, a reputation can consist of multiple underlying domains (Lange, Lee, \& Dai, 2011). A firm can be known for a "...particular attribute or characteristic: An organization has a reputation for something, such as having high quality products..." (Fischer \& Reuber, 2007 p. 57). Assessments of individual components of reputation arise from past actions, and influence what behaviors a stakeholder expects to see from a firm in the future (Deutsch \& Ross, 2003). In a similar vein, firms can engender assessments of various CSR domains. I.E. a firm which concentrates on strong environmental performance may have separate assessments of its actions regarding its employees, governance, etc. (Fombrun, Ponzi, \& Newburry, 2015). This idea forms one of the central questions of paper which asks what happens if a firm which has a reputation for strong performance in one CSR domain experiences a negative event in another.

For purposes of experimentation this paper focuses on two distinct categories of CSR. Since the research question does not pertain to a specific category per se, but rather to the general effects of category alignment, care was taken to select two domains which would be viewed as properly differentiated from each other. Previous authors have distinguished between CSR domains utilizing stakeholder focus as the category boundary. For example, (Hameed, Riaz, Arain, \& Farooq, 2016) utilized internal vs. externally focused actions for their analysis of employee-company identity. Other authors restricted their analyses to popular CSR disclosure dimensions such as community involvement and the natural environment (Hou \& Reber, 2011; Jin \& Lee, 2019). Following this precedent, conventions of Cornelius et al. (2008) the paper investigates employee relations (or employee-oriented) CSR and actions related to the natural environment. This utilizes one internally and one externally focused CSR domain targeting two distinct stakeholder groups. Further, these domains were selected with the assumption that continuing media focus on issues such as sustainability and labor relations would render these categories comprehensible by the average respondent.

\section{Corporate hypocrisy}

Put simply, corporate hypocrisy occurs when a firm claims to be something that it is not (Wagner et al., 2009), or its actions run counter to the image it is attempting to portray to its stakeholders. As a firm 
commits resources to a cause it is attempting to create associations between itself and socially desirable attributes in the eyes of stakeholders (i.e. "we care about the environment") (Brown \& Dacin, 1997), and is building expectations of future performance (de Quevedo-Puente, de la Fuente-Sabaté, \& DelgadoGarcía, 2007) .

We contend that this is analogous to both a claim about current state of being and an implicit promise, or an understood commitment to future performance. When information is revealed regarding behavior that contradicts previously held positions, the resulting dissonance may lead consumers to question the motives or authenticity of previous attributions (Lange \& Washburn, 2012), and may enhance negative reactions to wrongdoing (Wagner et al., 2009). This is evidenced by Janney and Gove (2011) who found that previous CSR reputation for corporate governance served to exacerbate the negative effects of governance-related wrongdoing. This is similar to logic found in the literature on "greenwashing" or the lack of substantive environmental action to match with firm rhetoric. A firm may claim to be green without offering any material commitments to sustainability (Walker \& Wan, 2012). In this situation, revelations about a firm's true nature may exacerbate the effects.

Conversely, when a failure occurs in a non-aligned area, consumers must evaluate the behavior in the absence of distinct claims regarding intended commitment. While previous research has established that good works in one CSR domain may carry over to beliefs in other areas (Klein \& Dawar, 2004), we hypothesize that the lack of concrete assertions in one area by the firm will lead to fewer future expectations regarding performance in that specific domain which will, in turn, produce fewer unfavorable attributions. Thus we arrive at the following hypothesis:

H1a: Perceived hypocrisy will be greater when the failure aligns with prior CSR reputation.

\section{Severity}

In addition to alignment, it is useful to consider the impact of failure severity on consumer reactions. Hypocrisy is a representation of the gap between communication and reality (Fassin \& Buelens, 2011). A relatively minor failure may represent a trivial contradiction to firm communication and may be seen by consumers as unavoidable, or largely unimportant. Conversely, a severe failure may represent a deliberate lapse in organizational conduct and may signal to consumers that there are significant problems with underlying processes. These attributions may drive the perceived dissonance between ideal conduct and actual behavior thereby leading to greater perceptions of hypocrisy (Fassin \& Buelens, 2011). Therefore:

\section{H1b: Failure severity will have a direct effect on perceived hypocrisy such that a more severe failure will lead to greater perceptions of hypocrisy.}

According to attribution theory, consumers look for causal explanations when presented with information (Kelley \& Michela, 1980). In the case of hypocrisy, when actions conflict with prior reports of CSR, consumers may elaborate upon the event and infer negative attributes as factors driving the behavior. These perceptions, in turn, may lower overall brand evaluations and decrease repurchase intent. This is supported by Wagner et al. (2009) who found that consumers experienced stronger negative affect when perceptions of hypocrisy were high. Further, since trust is dependent upon anticipated consistency of behavior, actions which contradict prior CSR reports may lead individuals to rate a firm as less trustworthy. Based on this assessment, we predict.

\section{H2: Perceived Hypocrisy will have a negative relationship with overall Brand Attitude, repurchase intent, and trust.}

\section{Study 1}

Study 1 employed a 2 Alignment (aligned/unaligned) $\times 2$ Severe (yes/no) mixed-methods experimental design. The impact of perceived hypocrisy on attitudes towards brands is a phenomenon which is expected to be found across the general population. Thus, we did not exclude anyone between the ages of 18-64 years old from participating in the study. That said, data was collected in the United States and thus will more than likely contain more U.S. citizens. In order to efficiently capture this population, data was collected using an online subject pool, Amazon Mechanical Turk, which provides high-quality data quickly and relatively inexpensively and Qualtrics, an online survey design and data collection tool. An initial sample of 223 respondents was achieved. However, 15 respondents were removed due to incomplete data or for failure to pass a comprehension check thereby bringing the total sample size to 207 (mean age $=31,65 \%$ male, 75\% Caucasian).

In order to establish experimental groups based on alignment, respondents were first exposed to one of two hypothetical scenario detailing a fictitious firm's social practices (either environmental or 
employee oriented CSR, see Appendix A) and asked to rate perceptions of the firm's CSR practices. Next, respondents were randomly presented with a scenario in which the same fictitious firm's actions resulted in a service failure either in the same domain of CSR practices (aligned) or in another domain of CSR practices (unaligned, see in Appendix B). Subjects were then asked to rate perceptions of the firm's CSR practices, as well as, level of perceived hypocrisy and a number of other outcome variables (e.g. Attitude Toward the Brand, Purchase Intentions, and Trust). All constructs, except for Brand Attitude, were measured using established threeitem 7-point Likert scales. Brand Attitude was measured using an established four-item 7-point semantic differential scale.

A pre-test was conducted to ensure the efficacy of the severity manipulations. A pool of 104 respondents were exposed to either the mild or severe failure in the environmental or employee-oriented CSR domain. Respondents were then asked to rate the severity of the failure using a 5-point likert scale. Independent sample t-tests were conducted to compare conditions. Results indicated a significant different between the mild environmental $(M=2.96$, $\mathrm{SD}=1.42)$ and severe environmental $(\mathrm{M}=4.07, \mathrm{SD}=$ 1.05) conditions; $\mathrm{T}(49)=-3.185, p=.003$. Likewise, results indicated a significant difference in the mild employee-oriented $(\mathrm{M}=3.2, \mathrm{SD}=1.08)$ and severe employee-oriented $(\mathrm{M}=3.79, \quad \mathrm{SD}=.88)$ conditions; $\mathrm{T}(47)=-2.094, p=.042$. Further tests revealed no significant differences between the environmental and employee-oriented scenarios in both the mild $(\mathrm{T}(48)=-.670, p=.506)$ and severe $(\mathrm{T}(48=1.032$, $P=.307)$ conditions, thus indicating no perceived difference between failure type.

\section{Method of analysis}

To test the hypotheses, we measured each variable of interest using vetted extant reflective multi-item scales. Each scale utilized seven-point rating scales with reflective multi-item measures. Constructs were developed using items adapted from previous literature (Bougie, Pieters, \& Zeelenberg, 2003; Shim \& Yang, 2016 ; Wagner et al., 2009). A mean score index of six items was used to measure perceived hypocrisy (Shim \& Yang, 2016; Wagner et al., 2009). On a 7point scale, ranging from 1 (strongly disagree) to 7 (strongly agree), participants were asked to indicate how strongly they agreed with statements such as "Star Inc. acts hypocritically," "Star Inc. is pretending to be something it is not," "Star Inc. pretends to be something that it is not," and "Star Inc. does exactly what it says." The index was $M=5.30, \mathrm{SD}=0.088$ and reliability was $\alpha=.953$.

To assess the overall brand attitude, a mean score index of four items was used (dislike-like, favorableunfavorable, bad-good, and positive-negative) on 7 point semantic differential scales. The index $(M=$ 3.07, $\mathrm{SD}=0.105)$ produced acceptable reliability $(\alpha=.983)$. Trust was assessed using a mean score index of three item 7-point Likert scales asking for agreement to items such as "Star Inc. is trustworthy" and "Star Inc. would meet my expectations." The index was $M=2.99, \mathrm{SD}=0.094$ and reliability was $\alpha=.913$. Lastly, to assess repurchase intentions, we utilized a mean score index of three items using a 7point Likert scales asking for agreement to items such as "Following the incident, I would consider buying a product from this company" and "Following the incident, there is a strong likelihood that I will buy a product from this company." The index was $M=3.17$, $\mathrm{SD}=0.106$ and reliability was $\alpha=.965$.

Structured equation modeling (SEM) using AMOS 21 was performed to statistically analyze the data. Test for data normality indicated no violations of assumptions. A confirmatory factor analysis (CFA) measurement model was conducted to assess unidimensionality, as well as, convergent and discriminate validity for each construct (Jöreskog \& Sörbom, 1986). The model indicated acceptable overall fit for all constructs individually and for the full model (Chi-Square $=301.86$, $p<.000)$, RMSEA $=.063$; CFI $=.98$; NFI $=.95$ ). Furthermore, convergent and discriminant validity tests were within acceptable levels and, therefore, indicate no issues in the data.

Since a questionnaire was used for data collection, there was an increased possibility of common methods bias (CMB). A second measurement model analysis including a common latent factor was performed and indicates no CMB present (Liang, Saraf, $\mathrm{Hu}, \&$ Xue, 2007). In addition, a recent paper determined that gender could have an impact on perceptions of CSR, moderating effect on the relationship between CSR perceptions and corporate brand equity, as well as CSR perceptions and perceptions of hypocrisy (Hur, Kim, \& Jang, 2016). Thus, we use gender as a control variable in all analyses.

\section{Results}

A structural equation model was constructed to test hypothesized relationships. Overall the model indicated good fit (RMSEA $=.078, \mathrm{CFI}=.992$, NFI $=.985)$. As shown in Fig. 1 , both alignment $(0=$ unaligned, $1=$ aligned $)$ and failure severity $(0=$ low, $1=$ high $)$ were positively related to perceived hypocrisy $(0.27$ and 0.26 , respectively) indicating support for $\mathrm{H} 1 \mathrm{a}$ and 


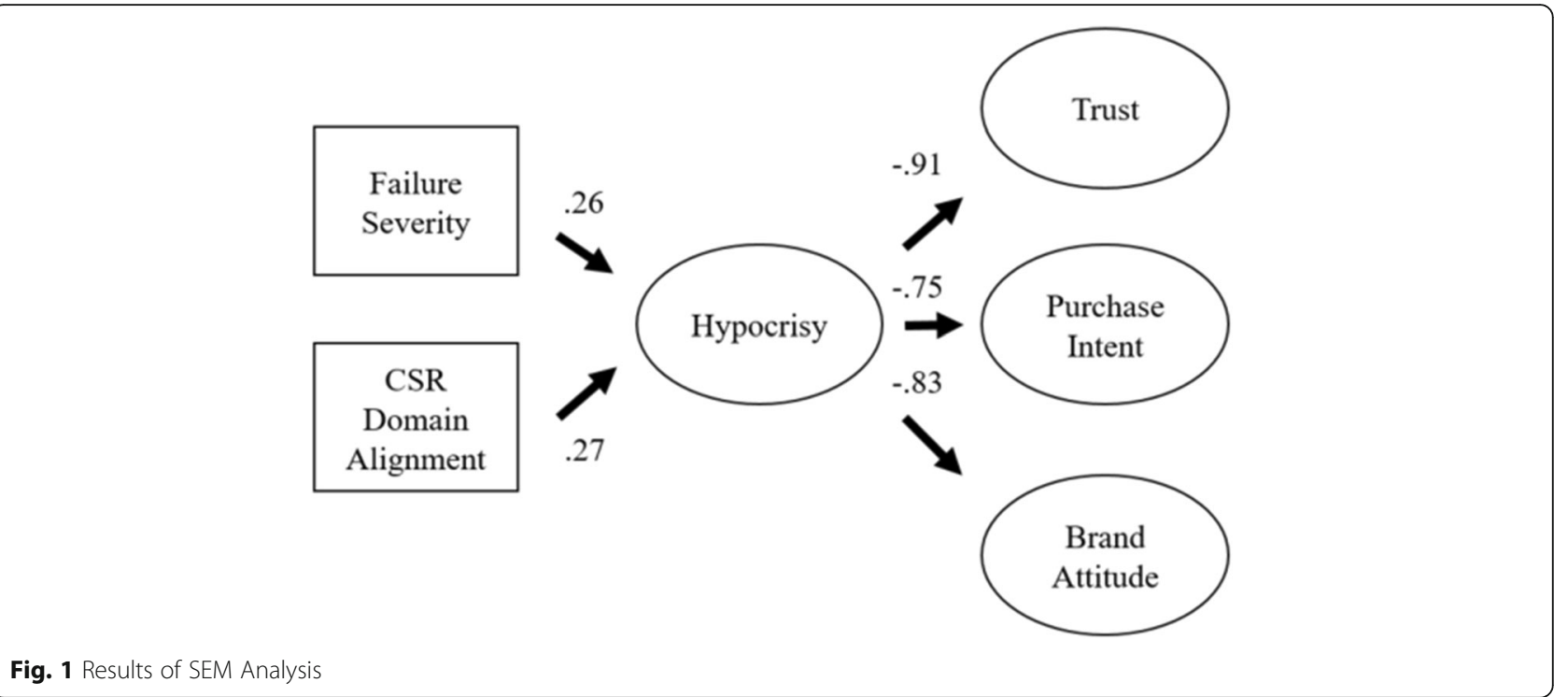

H2b. Furthermore, perceived hypocrisy was negatively related to brand attitude, repurchase intentions and trust $(-.83,-.75$ and -.91 respectively). Figure 1 shows the results of the research model.

\section{Study 2}

While study 1 demonstrates that perceived hypocrisy can have a deleterious effect on consumer responses and attitude, study 2 extends study 1 by investigating the effect of two post-failure response strategies (apology and compensation).

Corporate communications after a negative event can be an effective tool for reducing financial and reputational harm. Specifically, the issuance of an apology or compensation to victims is a common tactic used by organizations (Hearit, 2006) among other initiatives such as internal policy changes (Pfarrer, Decelles, Smith, \& Taylor, 2008), or social investments meant to restore the firm's image as an ethical actor (Noack, Miller, \& Smith, 2019).

Corporate crises and other reputation damaging events present the possibility of serious harm to a firm which can manifest in the form of reduced customer satisfaction (Xie \& Peng, 2009) negative reviews (Gelbrich, 2010) or even calls for boycotts (Makarem \& Jae, 2016). In essence, a hypocrisyinducing event can not only damage the trust afforded by various stakeholder groups, but may also lead to negative expectations about future performance. When apologizing, firms use rhetoric and public statements in an attempt to take responsibility for a crisis and repair damaged stakeholder relationships (Coombs \& Holladay, 2008). An apology represents an attempt to communicate remorse and guilt while asserting that such an action will not happen in the future (Pace, Fediuk, \& Botero, 2010).

Indeed, research has shown that apologies can blunt the negative effects of a corporate crisis. For example, Manika, Papagiannidis, and Bourlakis (2017) found that consumers were more likely to forgive a business, report higher levels of perceived trustworthiness, and had higher perceptions of overall brand favorability. Further, consumers were less likely to spread negative word-of-mouth following an apology regardless of whether they were directly or indirectly harmed by the firm (Casidy \& Shin, 2015).

Despite these findings, there have also been conflicting findings regarding apology type. Coombs and Holladay (2008) found that three recovery strategies (sympathy, apology and compensation) each had a similar effect on consumer anger following an organizational crisis. A partial explanation for this effect.

We hypothesize that in a situation where perceived hypocrisy is high (such as the aligned condition), rhetoric may be less effective due to the already perceived violation of an organization's implicit promises (I.E. "Talk is cheap"). When the organizational crisis is within the same domain as the firm's purported social responsibility competencies, an apology may be insufficient to rebuild trust amongst stakeholders or encourage forgiveness. However, when no apparent violation of previous commitments occurs (such as the unaligned condition), rhetoric may be sufficient to 
counter hypocrisy due to lower skepticism regarding the authenticity of past claims. In essence, when a firm commits a violation, stakeholders may have less Therefore:

H3a: When failure type is unaligned with prior CSR, perceived hypocrisy will be significantly reduced when a firm issues an apology vs. no response.

Conversely, a firm can respond with more substantial resource commitments such as through a pledge to pay for damages or to compensate stakeholders affected by the crisis. This works to restore inequity caused by the organization's failure (Smith, Bolton, \& Wagner, 1999). Using previous logic, when failure is aligned more intense resource commitments may be required to overcome the feelings of hypocrisy generated by the incident (I.E. "putting money where one's mouth is"), as substantive commitments may be more effective in repairing organizational image (Pfarrer et al., 2008). Therefore, in the case of an aligned failure we predict that a substantive commitment of resource via compensation will lead to the greatest reduction in perceived hypocrisy compared to other response options.

H3b: When failure type is aligned with prior CSR, perceived hypocrisy will be significantly reduced when a firm responds with monetary compensation compared to an apology or no response.

\section{Method of analysis}

To test the hypotheses in study 2, we again measured each variable of interest using vetted extant reflective multi-item scales. Each scale utilized seven-point rating scales with reflective multi-item measures. Constructs were developed using items adapted from previous literature (Bougie et al., 2003; Shim \& Yang, 2016; Wagner et al., 2009). We utilized the same mean score index of six items to measure perceived hypocrisy (Shim \& Yang, 2016; Wagner et al., 2009). For the Study 2, the index was $M=4.37, \mathrm{SD}=1.69$ and reliability was $\alpha=.961$.

A 2 Alignment (aligned/unaligned) $\times 2$ Severe (yes/no) $\times 3$ Response (no response/ apology/monetary compensation) mix method experimental design was employed for Study 2. Similar to study 1, we expect the phenomenon of study to be found across the general population. Thus again, we did not exclude anyone between the ages of 18-64 years old from participating in the study. Data was collected in the United States and thus will more than likely contain more U.S. citizens. Data was collected using an online subject pool, Amazon Mechanical Turk, in Study 2. A total of 279 respondents completed the survey. However, of those, 35 respondents were removed due to incomplete data or for failure to pass a comprehension check thereby bringing the usable sample size to 244 (mean age $=34,57 \%$ male, $75 \%$ Caucasian). The age was distributed across a wider range than in Study 1, with 91\% of respondents being between 19 and 54 years old. While allows for more confidence the generalizability of results.

Similar to study 1 , respondents were first exposed to one of two hypothetical scenario detailing a fictitious firm's social practices (either environmental or employee oriented CSR). Immediately following this prompt subjects assessed the firm's level of social responsibility. Next, subjects read a scenario involving a firm-level failure (see Appendix $\mathrm{C}$ for recovery scenarios). Those in the aligned condition were exposed to a failure in the same domain as the previously established social practices (I.E. environmental CSR environmental failure) while those in the unaligned condition were given a failure in the unrelated domain (I.E. environmental CSR - employee related failure). In addition to type, the failure scenarios were varied to reflect either a minor or severe failure. Subjects then rated the severity of the failure. Departing from study 1 , subjects were then given information about one of three organization responses consisting of either: 1) no response, 2) an apology, or 3. information regarding monetary compensation. After the prompts, perceived hypocrisy was measured and demographic information was collected.

A confirmatory factor analysis (CFA) measurement model was conducted to assess unidimensionality, as well as, convergent and discriminate validity for each construct using AMOS 21 (Jöreskog, et al., 1988). The model indicated acceptable overall fit for all constructs individually and for the full model $($ Chi-Square $=550.43(P=.000)$, RMSEA $=.056 ;$ CFI $=$ . .98 ; NFI $=.96$ ). Furthermore, convergent and discriminant validity tests were within acceptable levels and, therefore, indicate no issues in the data.

Since a questionnaire was used for data collection, there was an increased possibility of common methods bias (CMB). A second measurement model analysis including a common latent factor was performed and indicates no CMB present (Liang et al., 2007). As in the first study, we were concerned that gender might have a confounding effect on results, thus we control for it. 


\section{Results}

An ANCOVA was conducted on participants' rating of corporate hypocrisy. Results revealed a significant main effect for the covariate, Pre_CSR_Perc F(1, $248)=10.633, p<.01$. There was a significant main effect for Alignment, $\mathrm{F}(1,248)=13.479, p<.001$. In general, participants had greater perceptions of hypocrisy when the failure was aligned with prior CSR $(M=$ $4.67, \mathrm{SD}=1.63)$, than when it was unaligned $(\mathrm{M}=$ $4.03, \mathrm{SD}=1.60)$. Perception of failure severity exerted a significant effect $F(1,248)=87.660, p<.001$. Hypocrisy was rated higher by those who perceived the failure to be more egregious $(M=5.04, \quad S D=1.56)$ compared to those with a less severe rating $(M=3.54$, $\mathrm{SD}=1.35)$. A significant main effect for Response (none, apology, compensation) $\mathrm{F}(2,248)=24.615$, $p<.001$. A significant three-way interaction of response, severity and alignment $\mathrm{F}(2,248) 4.755, p<.01$ was present. To better understand the interaction of alignment, failure severity and response type, the effect of both failure severity and response type on hypocrisy was interpreted within levels of alignment.

\section{Unaligned failure}

In the unaligned failure condition, both main effects of perceived severity, $\mathrm{F}(1,124)=57.130, p<.001$ and response type, $\mathrm{F}(2,124)=16.400, p<.001$ were significant, but these effects were qualified by a significant two way interaction between perceived severity and response, $F(2,124)=11.257, \quad p<.001$. Simple contrast effects in the low perceived severity condition revealed no significant difference based on response. However, when perceived severity was high, simple contrasts showed a significant difference of hypocrisy when comparing both the no response and apology condition $(\mathrm{M}=5.847$ vs. $\mathrm{M}=4.888, \mathrm{t}=$ $2.59, p<.05)$, and the no response and compensation condition $(M=5.88$ vs. $M=3.24, t=6.73$, $p<.001)$. The effect of response type in the unaligned condition is displayed in Fig. 2. Collectively, these results provide support for $\mathrm{H} 3 \mathrm{a}$.

\section{Aligned failure}

In the aligned failure condition significant main effects were observed from both response type, $\mathrm{F}(2$, $123)=8.982, p<.001$, and perceived severity, $\mathrm{F}(1$, $123)=37.185, p<.001$. Interestingly, unlike in the unaligned condition, prior perceptions of CSR had no significant effect on hypocrisy. This suggests that beliefs about a firm's social performance my shield a firm from skepticism only when failures do not match that social domain. In contrast to the unaligned condition, the effect of response type did not vary based on perceived severity. Simple contrasts were conducted to compare response types across both failure severity conditions. In support of $\mathrm{H} 3 \mathrm{~b}$, compensation produced significantly lower feelings of hypocrisy compared to no response $(M=3.958$ vs. $M=5.183$,

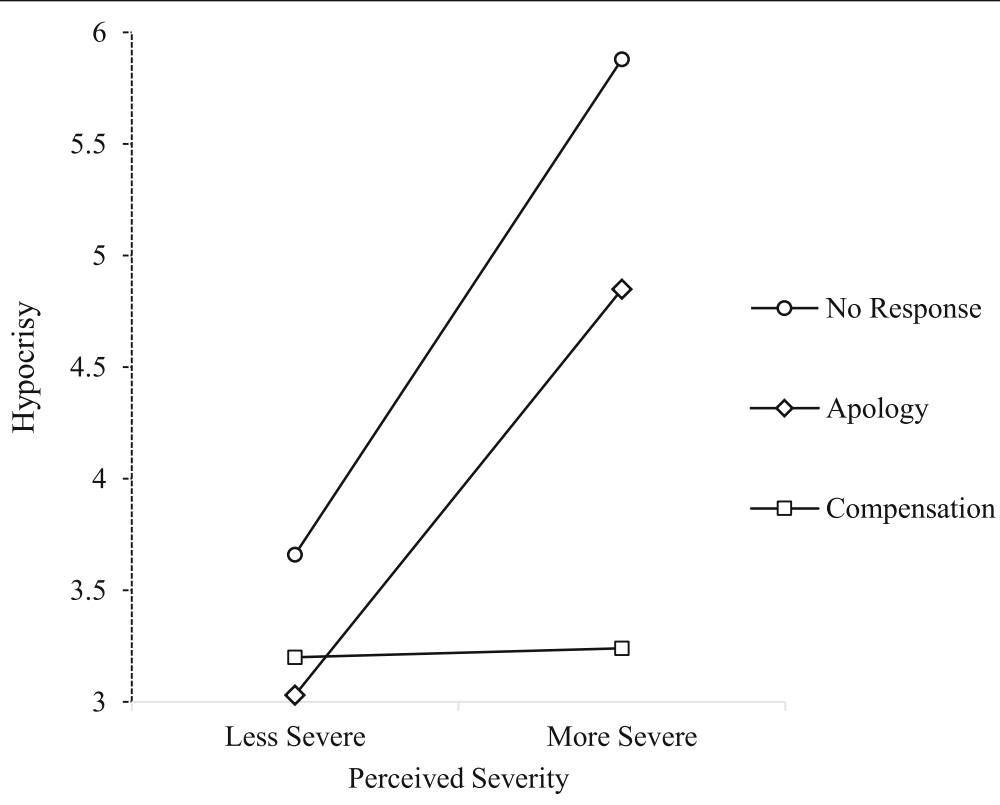

Fig. 2 Response Type by Perceived Severity for Unaligned Failures 
$\mathrm{t}=4.206, p<.001)$. There was no significant difference between apology and no response.

\section{Discussion}

Organizational failings present a serious problem for firm's as they might incur monetary loss, decreased sales, or potentially damage a business' reputation. Given the severity of these effects, scholars have devoted much research to understanding how loss following a negative event can be mitigated or repaired. To this end, much progress has been made in understanding how corporate citizenship and social performance can act as a buffering mechanism during a crisis, effectively shielding an organization from reputation damage. However, treating social performance as a singular construct when analyzing its effects after a negative event ignores the multidimensionality of CSR. To address this, and to contribute to the burgeoning literature on corporate hypocrisy, this study investigated how CSR sub-domains interact with failure type to influence perceptions of hypocrisy.

Both Study 1 and Study 2 investigate the effect of alignment and failure severity on perceived hypocrisy. Consistent with predictions, both the degree of failure alignment and failure severity had significant impacts on perceived hypocrisy which in turn led to a variety of deleterious effects on firm rating. Study 2 extends study 1 by investigating the effects of three response types on perceived hypocrisy following either an aligned or unaligned failure. Consistent with $\mathrm{H} 3 \mathrm{a}$ an apology resulted in a significant decrease in perceived hypocrisy when compared to no response. Likewise, as predicted in H3b, compensation resulted in a significant decrease in perceived hypocrisy while an apology had no effect. However, it should be noted that overall, the compensation strategy lead to the most significant reduction in perceived hypocrisy across both groups. This suggests that while a simple apology might be sufficient in limited contexts, overall customers may respond more favorable to substantive commitments of resources regardless of failure type.

The significance of these findings are twofold: first, it partially refutes the conceptualization of CSR as a buffer against firm wrongdoing. The buffering effect was observed but most notably in conditions where the organizational crisis did not match with the area of prior CSR reputation. Further, while a simple apology was enough to counteract some of the negative effects in the unaligned condition, in the aligned condition apology was no different from a non-response. This suggests that managers should consider the nature of the failure context in relation to firm reputation when crafting an organization response strategy.

\section{Limitations and future Research}

Both studies have limitations which provide a basis for future research. First, the samples for both studies were taken from a single cultural region which limits its generalizability. Culture and other regional characteristics might influence an individual's judgements about hypocrisy. In terms of hypocrisy, according to Effron, Markus, Jackman, Muramoto, and Muluk (2018) more interdependent, collectivist societies place greater emphasis the subordination of personal interests and are therefore more accustomed to behavior changes based upon context. In this situation, behavior which is inconsistent with past claims might generate less cognitive dissonance and may subsequently be viewed as less hypocritical. In contrast, a more individualistic society places greater emphasis on consistency of behavior (Suh, 2002) and actions which run contrary to past claims may be viewed as more self-serving.

In a similar vein, there is evidence to suggest that reactions to apology and apology type may differ across cultural contexts. Apologies utilized in the United States were found to have a greater emphasis on explanation whereas apologies in Japan placed more importance on showing remorse and promises to prevent future transgressions (Sugimoto, 1997). Some cultural groups have more concern regarding the status of the individual delivering the apology when accounting for communication channel (Sengupta, Ray, Trendel, \& Vaerenbergh, 2018). Further, in a China-US comparison respondents differed in importance placed on professional dress, body-language, and expressions of remorse (Song, Eslami, \& Galindo, 2018). Taken together, these factors provide future papers with ample opportunity to expand upon the relationship between hypocrisy, apology and recovery by including variations in national context.

While the paper controls for the effect of gender in the analysis, research in cognitive psychology suggests that gender differences may actually influence how an individual reacts to corporate apology both as the receiver and originator of the apology (Wei \& Ran, 2019). Future studies could investigate demographic differences and how they interact to determine perceptions of hypocrisy and the effectiveness of apology.

Due to a lack of a theoretical justification for selecting one CSR domain over another, this paper utilizes two categories which were meant to be immediately identifiable and comprehensible for respondents. Further research is needed to determine if perceived hypocrisy is influenced by aligned and unaligned pairings in other CSR domains. 


\section{Appendix A}

\section{Scenario Prompts}

\section{Reputation for Environmental CSR}

Star Inc. manufactures and sells a variety of affordable, yet fashionable clothing for all age groups.

Star Inc. takes pride in its commitment to the environment and sustainability and demonstrates this by only using environmentally friendly materials in its clothing. The company ensures that all waste generated by its manufacturing plant is disposed of in a safe and sustainable manner. Further, the company works to promote environmental sustainability outside of its business by donating $10 \%$ of each purchase to various conservation groups.

As proof of their efforts, Star Inc. has received many awards and recognition for environmental performance.

\section{Reputation for Employee-Oriented CSR}

Star Inc. manufactures and sells a variety of affordable, yet fashionable clothing for all age groups.

Star Inc. takes pride in its commitment to fair labor and human rights and demonstrates this by enforcing safety standards in its plants which are far more stringent than the law requires. The company routinely inspects its manufacturing plants both domestically and abroad to ensure workers are treated fairly and paid a livable wage. Further, the company works to promote human rights outside of its business by donating $10 \%$ of each purchase to various groups which fight to improve working conditions in less-developed countries.

As proof of their efforts, Star Inc. has received many awards and recognition for their commitment to people.

\section{Appendix B}

Table 1 Failure Prompts by CSR domain and Severity

\begin{tabular}{|c|c|c|}
\hline & Environmental & Employee-Oriented \\
\hline Minimal Severity & $\begin{array}{l}\text { Star Inc. Warned for Emissions } \\
\text { USA - The local Environmental Services Office issued a } \\
\text { warning to Star Inc. after a report released yesterday } \\
\text { found the company's manufacturing plant to be close to } \\
\text { violating the county's air-quality statutes. Under current } \\
\text { regulatory requirements, a factory of Star's size is allowed } \\
\text { to release up to } 1000 \text { pounds }(453 \mathrm{~kg} \text { ) of CO2 per month. } \\
\text { According to the report, emissions from the plant } \\
\text { approached } 950 \text { pounds }(499 \mathrm{~kg} \text { ) last month. }\end{array}$ & $\begin{array}{l}\text { Star Inc. Criticized for Labor Conditions } \\
\text { USA - Star Inc. has drawn criticism from local } \\
\text { interest groups after a report was released } \\
\text { today which found unsafe working conditions } \\
\text { at } 1 \text { of its } 6 \text { international plants. According to } \\
\text { the report, inadequate safety precautions at the } \\
\text { manufacturing facility have raised concerns } \\
\text { regarding the potential for future injuries. }\end{array}$ \\
\hline High Severity & $\begin{array}{l}\text { Star Inc. Cited for Violation } \\
\text { USA - The local Environmental Services Office has issued } \\
\text { a fine to Star Inc. after a report released yesterday found } \\
\text { the company's manufacturing plant to be in violation of } \\
\text { several environmental statutes. The report concludes that } \\
\text { Star Inc. was dumping untreated waste from its } \\
\text { manufacturing plant into local streams and rivers. Many } \\
\text { environmental groups are angry with Star and cite the } \\
\text { fact that its dumping is causing serious harm to local fish } \\
\text { and wildlife. }\end{array}$ & $\begin{array}{l}\text { Star Inc. criticized for labor conditions } \\
\text { USA - Star Inc. has drawn criticism from local } \\
\text { interest groups after a report was released today } \\
\text { which found poor working conditions at many of } \\
\text { its international plants. According to the report, at } \\
\text { some sites it was common for people to work up } \\
\text { to } 16 \text { h a day at rates that were less than minimum } \\
\text { wage. Many groups are angry with Star and cite } \\
\text { the fact that its practices are causing serious harm } \\
\text { to the local community. }\end{array}$ \\
\hline
\end{tabular}




\section{Appendix C}

Table 2 Apology Scenarios utilized in study 2

\begin{tabular}{ll}
\hline No Response & No additional information given \\
\hline Apology Only & After the events, Star Inc. released the following statement: \\
"It is with deep regret that we address the recent incident at our manufacturing facilities. & There is no excuse for our actions, and we at Star Inc. take full responsibility for the failings \\
that occurred. We recognize the harm this causes to the communities we operate in and to \\
everyone else connected to our business. We ask for both your forgiveness and understanding \\
as we move quickly to correct this situation." \\
After the events, Star Inc. released the following statement: \\
"It is with deep regret that we address the recent incident at our manufacturing facilities. \\
In order to correct the problem, Star Inc. will pay for all costs associated with the incident \\
and further invest resources to ensure this does not happen again. To prove our \\
commitment, we have already established an emergency relief fund and have begun \\
compensating those involved."
\end{tabular}

\section{Appendix D}

Description of Scales

CSR Attitude Pretest \& Post (CSRAtt)

7-point Likert Scale.

Items:

1. Star Inc. is a socially responsible company.

2. Star Inc. is concerned about improving society

3. Star Inc. Follows high ethical standards

Severity.

7-point differential scale.

Items:

I feel that this incident is

1. Not at all Serious - Very Serious

2. Not severe - Very Severe

3. Not harmful - Very harmful

Hypocrisy.

7-point Likert Scale.

Items:

1. Star Inc. acts hypocritically

2. What Star Inc. says and does are two different things

3. Star Inc. pretends to be something it is not

4. Star Inc. does exactly what it says

5. Star Inc. keeps its promises

6. Star Inc. puts its words into action

Attitude towards Brand (BrandATT). 7-point Differential Scale.

Items:

After the incident, my opinion of the business would be...

1. Dislike - Like

2. Unfavorable - Favorable
3. Bad - Good

4. Negative - Positive

Trust.

7-point Likert Scale.

Items:

1. Star Inc. is trustworthy

2. Star Inc. would meet my expectations

3. I cannot trust Star Inc. to be good

Negative Word of Mouth (NWOM).

Original scale is from Shim and Yang (2016).

7-point Likert Scale.

Items:

Because of this incident, I would...

1. ...spread negative word-of-mouth about Star Inc.

2. ... speak badly about Star Inc. to my friends

3. ... tell my friends not to deal with Star Inc.

4. ... for quality control please answer strongly agree

Purchase Intentions.

7-point Likert Scale.

Items:

Following this incident,

1. ...I would consider buying a product from this company

2. ...I would purchase a product from the company

3. ...there is a strong likelihood that I will buy a product from this company

Abbreviations

CFA: Confirmatory Factor Analysis; CMB: Common-Method Bias;

CSR: Corporate Social Responsibility; SEM: Structural Equation Modeling

\section{Acknowledgements}

The authors would like to thank the anonymous reviewers and the editor for their insights during the review process. 


\section{Authors' contributions}

DS prepared the first draft and collected initial survey data. ER performed and wrote details of the analysis. Both authors contributed to and approved the final draft of paper.

\section{Funding}

Not applicable.

\section{Availability of data and materials}

The data consist of survey interviews collected by the authors. It will be made available by reasonable request.

\section{Competing interests}

The authors declare that they have no competing interests.

\section{Received: 10 September 2019 Accepted: 24 December 2019} Published online: 12 March 2020

\section{References}

Bougie, R., Pieters, R., \& Zeelenberg, M. (2003). Angry customers don't come back, they get back: The experience and behavioral implications of anger and dissatisfaction in services. Journal of the Academy of Marketing Science, 31(4) 377-393.

Brown, T. J., \& Dacin, P. A. (1997). The company and the product: Corporate associations and consumer product responses. Journal of Marketing, 61(1), 68-84.

Carroll, A. B. (1991). The pyramid of corporate social responsibility: Toward the moral management of organizational stakeholders. Business Horizons, 34(4), 39-48.

Casidy, R., \& Shin, H. (2015). The effects of harm directions and service recovery strategies on customer forgiveness and negative word-of-mouth intentions. Journal of Retailing and Consumer Services, 27, 103-112.

Cone Communications. (2017). 2017 Cone communications CSR study. Retrieved from https://www.conecomm.com/2017-cone-communications-csr-study-pdf.

Coombs, W. T., \& Holladay, S. J. (2008). Comparing apology to equivalent crisis response strategies: Clarifying apology's role and value in crisis communication. Public Relations Review, 34(3), 252-257.

Cornelius, N., Todres, M., Janjuha-Jivraj, S., Woods, A., \& Wallace, J. (2008). Corporate social responsibility and the social enterprise. Journal of Business Ethics, 81(2), 355-370.

Dahlsrud, A. (2008). How corporate social responsibility is defined: An analysis of 37 definitions. Corporate Social Responsibility and Environmental Management 15(1), 1-13

de Quevedo-Puente, E., de la Fuente-Sabaté, J. M., \& Delgado-García, J. B. (2007) Corporate social performance and corporate reputation: Two interwoven perspectives. Corporate Reputation Review, 10(1), 60-72.

Deutsch, Y., \& Ross, T. W. (2003). You are known by the directors you keep: Reputable directors as a signaling mechanism for young firms. Management Science, 49(8), 1003-1017.

Effron, D. A., Markus, H. R., Jackman, L. M., Muramoto, Y., \& Muluk, H. (2018). Hypocrisy and culture: Failing to practice what you preach receives harsher interpersonal reactions in independent (vs. interdependent) cultures. Journal of Experimental Social Psychology, 76, 371-384

Fischer, E., \& Reuber, R. (2007). The good, the bad, and the unfamiliar: The challenges of reputation formation facing new firms. Entrepreneurship Theory and Practice, 31(1), 53-75.

Fassin, Y., \& Buelens, M. (2011). The hypocrisy-sincerity continuum in corporate communication and decision making. Management Decision, 49(4), 586-600.

Fombrun, C. J., Ponzi, L. J., \& Newburry, W. (2015). Stakeholder tracking and analysis: The RepTrak ${ }^{\oplus}$ system for measuring corporate reputation. Corporate Reputation Review, 18(1), 3-24.

Gelbrich, K. (2010). Anger, frustration, and helplessness after service failure: Coping strategies and effective informational support. Journal of the Academy of Marketing Science, 38(5), 567-585.

Godfrey, P. C. (2005). The relationship between corporate philanthropy and shareholder wealth: A risk management perspective. The Academy of Management Review, 30(4), 777-798.

Godfrey, P. C., Merrill, C. B., \& Hansen, J. M. (2009). The relationship between corporate social responsibility and shareholder value: An empirical test of the risk management hypothesis. Strategic Management Journal, 30(4), 425-445.
Hameed, I., Riaz, Z., Arain, G. A., \& Farooq, O. (2016). How do internal and external CSR affect employees' organizational identification? A perspective from the group engagement model. Frontiers in Psychology, 7, 788.

Hearit, K. M. (2006). Crisis management by apology: Corporate responses to allegations of wrongdoing. Mahwah: Lawrence Erlbaum.

Hou, J., \& Reber, B. H. (2011). Dimensions of disclosures: Corporate social responsibility (CSR) reporting by media companies. Public Relations Review, 37(2), 166-168.

Hur, W., Kim, H., \& Jang, J. H. (2016). The role of gender differences in the impact of CSR perceptions on corporate marketing outcomes. Corporate Social Responsibility and Environmental Management, 23(6), 345-357.

Ioannou, I., Kassinis, G. I., \& Papagiannakis, G. (2018). All are not saints, who go to church: Corporate social responsibility, perceived corporate hypocrisy and the impact on customer satisfaction. In Who go to church: Corporate social responsibility, perceived corporate hypocrisy and the impact on customer satisfaction Working paper.

Janney, J. J., \& Gove, S. (2011). Reputation and corporate social responsibility aberrations, trends, and hypocrisy: Reactions to firm choices in the stock option backdating scandal. Journal of Management Studies, 48(7), 1562-1585.

Jin, C.-H., \& Lee, J.-Y. (2019). The halo effect of CSR activity: Types of CSR activity and negative information effects. Sustainability, 11(7), 2067.

Jöreskog, K. G.. \& Sörbom, D. (1986). LISREL VI: Analysis of linear structural relationships by maximum likelihood, instrumental variables, and least squares methods. University of Uppsala, Department of Statistics.

Kelley, H. H., \& Michela, J. L. (1980). Attribution theory and research. Annual Review of Psychology, 31(1), 457-501.

Kim, S. (2014). What's worse in times of product-harm crisis? Negative corporate ability or negative CSR reputation? Journal of Business Ethics, 123(1), 157-170.

Kim, Y., \& Woo, C. W. (2019). The buffering effects of CSR reputation in times of product-harm crisis. Corporate Communications: An International Journal, 24(1), 21-43.

Klein, J., \& Dawar, N. (2004). Corporate social responsibility and consumers' attributions and brand evaluations in a product-harm crisis. International Journal of Research in Marketing, 21(3), 203-217.

Lai, C. S., Chiu, C. J., Yang, C. F., \& Pai, D. C. (2010). The effects of corporate social responsibility on brand performance: The mediating effect of industrial brand equity and corporate reputation. Journal of Business Ethics, 95(3), 457-469.

Lange, D., Lee, P. M., \& Dai, Y. (2011). Organizational reputation: A review. Journal of Management, 37(1), 153-184.

Lange, D., \& Washburn, N. T. (2012). Understanding attributions of corporate social irresponsibility. The Academy of Management Review, 37(2), 300-326.

Lenz, I., Wetzel, H. A., \& Hammerschmidt, M. (2017). Can doing good lead to doing poorly? Firm value implications of CSR in the face of CSI. Journal of the Academy of Marketing Science, 45(5), 677-697.

Liang, H., Saraf, N., Hu, Q., \& Xue, Y. (2007). Assimilation of enterprise systems: The effect of institutional pressures and the mediating role of top management. MIS Quarterly, 37(1) 59-87.

Manika, D., Papagiannidis, S., \& Bourlakis, M. (2017). Understanding the effects of a social media service failure apology: A comparative study of customers vs. potential customers. International Journal of Information Management, 37(3), 214-228.

Matten, D., \& Moon, J. (2008). "Implicit" and "explicit" CSR: A conceptual framework for a comparative understanding of corporate social responsibility. The Academy of Management Review, 33(2), 404-424.

McWilliams, A., \& Siegel, D. (2000). Corporate social responsibility and financial performance: Correlation or misspecification? Strategic Management Journal, 21(5), 603-609.

Makarem, S. C., \& Jae, H. (2016). Consumer boycott behavior: An exploratory analysis of twitter feeds. Journal of Consumer Affairs, 50(1), 193-223.

Noack, D., Miller, D. R., \& Smith, D. (2019). Let me make it up to you: Understanding the mitigative ability of corporate social responsibility following product recalls. Journal of Business Ethics, 157(2), 431-446.

Öberseder, M., Schlegelmilch, B. B., \& Murphy, P. E. (2013). CSR practices and consumer perceptions. Journal of Business Research, 66(10), 1839-1851.

Pace, K. M., Fediuk, T. A., \& Botero, I. C. (2010). The acceptance of responsibility and expressions of regret in organizational apologies after a transgression. Corporate Communications, 15(4), 410-427.

Peloza, J. (2006). Using corporate social responsibility as insurance for financial performance. California Management Review, 48(2), 52.

Pfarrer, M. D., Decelles, K. A., Smith, K. G., \& Taylor, M. S. (2008). After the fall: Reintegrating the corrupt organization. The Academy of Management Review, $33(3), 730-749$ 
Pollach, I. (2015). Strategic corporate social responsibility: The struggle for legitimacy and reputation. International Journal of Business Governance and Ethics, 10(1), 57-75.

Sengupta, S., Ray, D., Trendel, O., \& Vaerenbergh, Y. V. (2018). The effects of apologies for service failures in the global online retail. International Journal of Electronic Commerce, 22(3), 419-445.

Shim, K., \& Yang, S. U. (2016). The effect of bad reputation: The occurrence of crisis, corporate social responsibility, and perceptions of hypocrisy and attitudes toward a company. Public Relations Review, 42(1), 68-78,

Smith, A., Bolton, R., \& Wagner, J. (1999). A model of customer satisfaction with service encounters involving failure and recovery. Journal of Marketing Research, 36(3), 356-372.

Song, S.-C., Eslami, Z. R., \& Galindo, K. B. (2018). Public apologies and intercultural communication: Perceptions of Chinese and American students. Intercultural Communication Education, 1(1), 27-44.

Sugimoto, N. (1997). A Japan-US comparison of apology styles. Communication Research, 24(4), 349-369.

Suh, E. M. (2002). Culture, identity consistency, and subjective well-being. Journal of Personality and Social Psychology, 83(6), 1378.

Tetrault Sirsly, C. A., \& Lvina, E. (2019). From doing good to looking even better: The dynamics of CSR and reputation. Business \& Society, 58(6), 1234-1266.

Wagner, T., Lutz, R. J., \& Weitz, B. A. (2009). Corporate hypocrisy: Overcoming the threat of inconsistent corporate social responsibility perceptions. Journal of Marketing, 73(6), 77-91.

Walker, K., \& Wan, F. (2012). The harm of symbolic actions and green-washing: Corporate actions and communications on environmental performance and their financial implications. Journal of Business Ethics, 109(2), 227-242.

Wei, H., \& Ran, Y. (2019). Male versus female: How the gender of apologizers influences consumer forgiveness. Journal of Business Ethics, 154(2), 371-387.

Westphal, J. D., \& Deephouse, D. L. (2011). Avoiding bad press: Interpersonal influence in relations between CEOs and journalists and the consequences for press reporting about firms and their leadership. Organization Science, 22(4), 1061-1086.

Xie, Y., \& Peng, S. (2009). How to repair customer trust after negative publicity: The roles of competence, integrity, benevolence, and forgiveness. Psychology and Marketing, 26(7), 572-589.

\section{Publisher's Note}

Springer Nature remains neutral with regard to jurisdictional claims in published maps and institutional affiliations.

\section{Submit your manuscript to a SpringerOpen ${ }^{\circ}$ journal and benefit from:}

- Convenient online submission

- Rigorous peer review

- Open access: articles freely available online

High visibility within the field

- Retaining the copyright to your article

Submit your next manuscript at $\boldsymbol{\nabla}$ springeropen.com 